\title{
International Portfolio Diversification - Role of Emerging Economies-US Integration and Dynamic Linkages: An Empirical Study
}

\author{
Ranjan Dasgupta ${ }^{1}$ \\ ${ }^{1}$ Xavier University Bhubaneshwar (XUB), India \\ Correspondence: Ranjan Dasgupta, Assistant Professor, Xavier University Bhubaneshwar (XUB), India. Tel: \\ 0674-237-7700 Ext: 7750. E-mail: ranjandasgupta@ximb.ac.in, dasguptaranjan75@gmail.com
}

Received: March 14, 2016

Accepted: May 18, 2016

Online Published: May 25, 2016

doi:10.5539/ijef.v8n6p100

URL: http://dx.doi.org/10.5539/ijef.v8n6p100

\begin{abstract}
This paper presents a comprehensive research by studying the cointegration and dynamic linkages of emerging economies all over the world with special emphasis to the US and India to point out the most attractive of them for international portfolio diversification with a lengthy data set of 2003-12 by using appropriate methodologies. It is found that the Indian stock market has short-run granger relationships with most of its BRIC counterparts and some others. In the long-run, nine co-integration relationships are found. It implies that all these stock markets are cointegrated. The US dominance on most markets and dynamic linkages with them has been proved, at least in the short-run. Overall, this study has found that the emerging economies stock markets and Russia don't provide any portfolio diversification opportunity for the US and other investors.
\end{abstract}

Keywords: US and emerging economies stock markets, integration \& dynamic linkages, JJ cointegration tests, pairwise granger causality tests, impulse response functions

\section{Introduction}

The degree of stock market integration throughout the world has developed enormously and significantly during the late 1980s onwards. Some of the key motivators driving this scenario have been the adoption of liberalization policies in different countries of the world especially emerging economies like India, China, etc., deregulation of domestic stock markets, advancement of Information and Communication Technologies (ICTs), international portfolio diversification strategies to reap maximum profits by institutional investors, above-normal growth numbers in many emerging economies, stricter regulations and corporate governance (CG) approach by domestic companies, and a shift in the risk preference of domestic companies from debt to equity capital.

However, integration and interdependence of international stock markets do come with its own pros and cons. In the positive side, free flow of funds across borders induce countries to step forward in the path of stock market reforms, and follow more disciplined macroeconomic policies that translate into greater macroeconomic stability. Sound markets help in effective price discovery, developing depth and breadth, unrestricted information transmission, lowering transaction costs and thereby higher profits. All these in turn lead to efficient stock market and leading to increased savings, investment and overall economic progress for a country. But, international stock market integration has its disadvantages also. If international stock markets move in tandem, then investing in such international markets does not reap any long-term gains from portfolio diversification. During crises such as the Asian financial crisis in 1997 and the very recent credit crisis in 2008 in the United States of America (USA), it is observed that integrated stock markets do crumble simultaneously.

Integration of financial market has been defined differently by various researchers all these years. This study follows Kearney and Lucey's (2004) idea that there are three approaches for defining international stock market integration - equalizing the rates of returns, international capital market completeness, and domestic investment sourcing. The first approach which is used under this study to define stock market integration is the direct approach based on the law of one price, i.e., stock market indices which have the similar risk characteristics should command similar returns under the condition of unrestricted cross-border capital flows. The Reserve Bank of India (RBI) (2007) put the operational definition in this regard by pointing out that the unification of various stock markets leads to convergence of risk-adjusted returns. Also, the progress of domestic, regional, and 
global financial integration can be measured using a number of approaches. Generally, these measures can also be divided into three categories - institutional/regulatory measures, quantity, and price-based measures. This study uses price-based measure of stock market integration.

According to the Markowitz's (1952) 'modern portfolio theory', the benefits of portfolio diversification in international stock markets and indices can be reaped only when two stock markets have low correlation, i.e., they are independent and not integrated. But, over the time, as economies opened up and became more liberalized, integration of global stock markets becomes unavoidable (Bekaert et al., 2002). Thus, it is critical to study whether there is a change in the relationships of the US stock market with the other emerging economies stock markets. If integration exists, the strategy of diversifying US investors' portfolio in these stock markets may no longer apply.

Thus, it is immensely critical for the policy-makers, investors - domestic and international, market participants, and all other stakeholders interested in investing in international stock markets to judge the degree of integration and interdependence in between them. Researchers and academicians also have taken keen interest in finding the nook and corners of stock market integration internationally. The question to think upon under this study is whether this co-movement has been a short-run phenomenon or the selected stock markets across the globe are integrated in the long-run?

This study specifically aims at finding the degree of integration of the US stock market with that of the emerging economies and one extremely important rentier, i.e., Russia (see Bensidoun et al., 2009). Bensidoun et al. (2009) also pointed out that in the group of emerging economies, there are four 'large emerging economies' (LEEs) defined as those accounting for more than $1 \%$ of world Gross Domestic Product (GDP) (in current dollars term) - China, India, Brazil, and Mexico. So, this study incorporates all these LEEs. Being a very important element of BRIC, Russia also accounts for $1 \%$ of world GDP (in current dollars term). This study has also undertaken Indonesia and Philippines as ASEAN representatives, and Turkey as an emerging economy from Europe. Also, it has the objective to find out which of the above emerging economies is the best possible destination for the US investors to diversify their investments. Special emphasis is provided to the Indian stock market being the most attractive among emerging economies in terms of annual GDP growth and future potential.

Bekaert et al. (2002) observed that integration of international stock market is a time-varying concept. Thus, longitudinal studies should be undertaken to get authentic results. Thereby, this study has undertaken the sample period of ten years, i.e., 2003-12. This study uses graphical presentations, descriptive statistics results (to verify the normality and nature of the data series), correlation test results, Augmented Dickey-Fuller (ADF) (Dickey \& Fuller, 1979; 1981) tests and Phillips-Perron (PP) (1988) tests (to find out if there is non-stationarity), Johansen and Juselius's (JJ) (1990) cointegration technique, and Granger's (1969) pairwise causality tests. Impulse response analysis will also be conducted to find the information transmission in between studied markets under this study.

The rest of the paper is organized as follows. A survey of the existing relevant literature including empirical evidences on short and long-run integration, and dynamic linkages in between the US and selected emerging economies stock markets is undertaken in Section 2. Section 3 presents descriptions of data for this study and discusses research methodology used for investigation and analysis purposes. Section 4 reports empirical results and subsequent discussions followed by conclusion in Section 5 .

\section{Literature Review}

The research in the area of cointegration among world stock markets began in 1968 with Grubel's seminal paper (1968). It was followed by Agmon (1972), Hilliard (1979), Becker et al. (1990), and Hamao et al. (1990), to name a few. Their work primarily focused on the correlation among the then developed markets, namely, the USA, the UK, Germany and Japan. The objective was to ascertain whether international portfolio diversification would be beneficial or not. The results broadly indicated that the markets did have some cointegration, but the correlation was low. Developments in stock markets led to more research in this area using more sophisticated analytical techniques. Not only the correlation and co-movement were studied but also the focus was expanded to the structure of the inter-linkages (Eun \& Shim, 1989).

Cheung and Mak (1992), and Masih and Masih $(1997 ; 1999 ; 2002)$ found that the US market is a global factor affecting both the developed and developing markets. Chan (2002) quoted- "The financial market in United States has long been seen as the leader of global financial market". Also, the US was found to be the most influential stock market (Eun \& Shim, 1989; Hamao et al., 1990; Becker et al., 1990; and Liu et al., 1998) and proved to have a significant influence on the Asia-Pacific markets, and the integration is shown to have started after the stock market crash of 1987 and/or the Gulf War of 1991 (e.g., Arshanapalli et al., 1995; Ghosh et al., 
1999; Siklos \& Ng, 2001; etc.). So, this study has undertaken the US stock market as the centre to investigate other emerging economies stock markets degree of integration around it.

Since the present study is employing Johansen and Juselius's (1990) cointegration and Granger's (1969) pairwise causality tests mainly to investigate the long-run and short-run integration and dynamic linkages among the US and other emerging economies (and one rentier) (see Bensidoun et al., 2009) stock markets representing Asia, America, and Europe, therefore, literature review is limited to only such relevant studies.

Park (1999) found that the degree of financial integration internationally has been increasing modestly in the recent decades both for the developed and developing countries. Among the developed countries the variance of such cointegration is relatively large vis-à-vis developing countries. He concluded that among the developing countries, India is the least active in the process of integration at least through 1997. However, Agarwal (2000) concluded that there is a lot of scope for the Indian stock market to integrate with the world markets. Mukherjee and Mishra (2007) analyzed 23 markets, and identified increasing tendency of integration among these markets. They also discovered that countries of same region are found to be more integrated than others. So, this study has mainly concentrated on the emerging economies from Asia.

In one of the earliest studies in between the US and India, Ignatius (1992) compared returns on the BSE Sensex with those on the NYSE S\&P 500 Index and found no evidence of integration. Arshanapalli and Kulkarni (2001) studied the interdependence between India and the US stock market and results showed that the former was not dependent on the later market. Mishra (2002) also found no cointegrating vector between the BSE and NASDAQ indices that implies that there was no long-run relationship between these two stock exchanges.

Bose (2005) examined the inter-linkages between the Indian stock market, and the Asian stock markets and the US using daily data from January $1^{\text {st }}, 1999$ to June $30^{\text {th }}$, 2004. She found that post-Asian crisis and up to mid-2004, India was highly correlated with major Asian markets' indices returns and was led by returns in the US, Japan, as well as other Asian markets. On the other hand, the Indian BSE Sensex return was also seen to exert some influence on stock returns in some important Asian markets. However, Mukharjee and Mishra (2005) by using the Granger's causality test and unidirectional Geweke feedback statistics proved the fact that though the Indian stock market have some influence on the stock market of some of the Asian countries, but the stock markets of European and American countries are not at all influenced/caused by it. Choudhry (1997) investigated the Latin American stock markets and the US stock market using cointegration technique. Thus, it is interesting to study the impact of the selected Asian, European, and Latin counterparts on the Indian stock market.

Click and Plummer (2005) observed that although the original five ASEAN nations, namely, Malaysia, Thailand, Singapore, the Philippines, and Indonesia were cointegrated in the economic sense, the integration was far from being complete. Dunis and Shannon (2005) also found long-run relationships among emerging markets from south-east Asia (Indonesia, Malaysia, and the Philippines), and central Asia (Korea, China, Taiwan, and India) with the three established markets, the US, UK, and Japan over the period $31^{\text {st }}$ August, 1999-29 ${ }^{\text {th }}$ August, 2003. In an interesting study, Ghosh et al. (1999) found that Hong Kong, Malaysia, India, and South Korea are closely linked with the US market, while Philippines, Indonesia, and Singapore have stronger ties with Japan. Majid et al. (2008) found long-run relationships for five ASEAN countries with the US and Japan only in the post-crisis period, while Awokuse et al. (2009) evidenced that the number of co-integrating vectors increases in the post-crisis period among 11 Asian economies.

Empirical studies have given special attention to the BRIC (Brazil, Russia, India, and China) stock markets integration and dynamic linkages all these years. The US market is attached with these in most such studies. This study presents some of the most significant ones in this regard.

Chen et al. (2006) examined the relation between India-US, US-China, and India-China employing Fractionally Integrated VECM to study co-integration between them. By supplementing the model with a multivariate GARCH model, it was observed that all these pairs are fractionally cointegrated. The US market played a dominant role while there remained an interactive relationship between the US and Chinese stock markets.

Chittedi (2009) empirically investigated the long-run equilibrium relationship between the BRIC stock markets and the stock market indices of three major developed countries (i.e., the US, UK, and Japan) by using multivariate cointegration to investigate the long-run relationships. To assess the short-run influence of markets and how many days each market takes to factor out the influence of the Indian stock market, they used the Granger causality tests with 02 days. The study found that the US, and Japan market factors influencing the Indian stock market. However, the Indian stock market is not influenced by the UK, Russia, Brazil, and Chinese markets. But, the Indian stock market is influencing Brazilian and Russian markets. The study finally concluded that India and developed countries markets the US, UK, Japan, and other Emerging BRIC markets are highly 
cointegrated during the period of the study.

Bhar and Nikolova (2009) explored the level of cointegration of the BRIC with their respective regions and the world in the post-liberalization period. They found that India has the highest level of integration on a regional and world level amongst the BRIC countries followed by Brazil, Russia, and lastly China. The study also suggested the existence of diversification opportunities for China, given its closed nature of the financial system. Another study on co-movement among selected stock market conducted by Modi et al. (2010) found that the correlation of BSE (India) with BVSP (Brazil), MXX (Mexico), FTSE100 (UK), DJIA and NASDAQ (US) is low. Therefore, these combinations provide attractive portfolio diversification opportunities for the US and Indian investors.

An and Brown (2010) examined the co-movements of the weekly and monthly index returns of the US, Brazil, Russia, India, and China stock markets during October 13, 1995-October 13, 2009. As expected, unit-root tests for the overall period indicated that stock prices are non-stationary, but stock returns are generally stationary for all indexes. Their findings indicated that there is some cointegration between the US and China, while there is no cointegration between the US and the other emerging markets by themselves. Therefore, all the BRIC stock markets excepting China provide attractive portfolio diversification opportunities for global investors.

Dasgupta $(2013$; 2014) found that the Indian stock market has strong impact on Brazilian and Russian stock markets. The interdependencies (mainly on India and China) and time-variant linkages are also evident in the BRIC stock markets. Overall, both the studies have found that BRIC stock markets are the most favourable destination for global investors in the coming future and among the BRIC the Indian stock market (Dasgupta, 2014) and the Chinese stock market (Dasgupta, 2013) has the dominance.

So, it is quite evident that the empirical results in relation to BRIC and the US are contradictory in nature. It implies that these kinds of time series indices and/or returns studies are always providing some interesting conclusions in regard to market-to-market integration and dynamic linkages. The international portfolio diversification options also thereby keep changing from one study to another.

Çıtak and Gözbaşı (2006) investigated the long-run cointegration relationship between ISE and stock markets of the USA, Germany, England, Japan, India, and Malaysia in 1986-2006 period on the one hand and the effects of financial liberalization on integration in the mentioned period on the other hand. They concluded that there is integration between ISE and the UK and Germany, and partial integration between ISE and the US and India's basic indexes in 1986-2006 periods. In addition, in 2000-2006 sub-periods they detected integration between the ISE and India, and partial integration between the ISE and Japan's basic indexes.

Erbaykal et al. (2008) by using cointegration tests on the monthly data covering a period of 1997:03-2007:06 found that Bovespa has a major effect on the ISE. Aktar (2009) revealed bidirectional causality for the Turkish and Russian stock indices.

Though there are many integration studies all over the world using multiple timeframes, time-frequency of data, different situations, and by using different methodologies, but this study has undertaken a unique combination of countries based on US vs. other emerging economies (and one rentier) representative of all continents. Thus, this present study contributes significantly to the existing body of literature of integration and dynamic linkages. It is also an attempt to fill the research-gap of researches on Indian and American (as a whole) stock markets integration. This is also the first time that international indices such as the ISE Istanbul National-100 Index and IPC All-Share Index are tagged with the Indian stock market. So, in all these regards this study is one of a pioneering nature.

\section{Methodology}

Generally, Correlation analysis is employed for judging short-run dynamic linkages and integration, and Granger causality test is employed to find the cause and effect relationships among international stock markets. So, this study applies a simple correlation test to measure the strength and direction of the association between the selected stock indices. Here, in its true sense, it denotes the interdependency and co-movement of S\&P 500 and BSE Sensex's returns with that of other international stock indices' returns. However, Leong and Felmingham (2001) found that correlation test results do not provide a sound basis for studies finding interdependence. This is because correlation coefficients are known to be upward-biased if the stock indices have heteroskedastic elements.

Thus, it is clear that a simple correlation test only measures the degree of linear association between two variables, and hence provides little insight on the dynamic linkages and causality between selected stock markets. Therefore, investigation of these stock markets' integration is to be extended by employing Granger's (1969) 
pairwise causality tests. Granger (1969) observed that a time series $X_{t}$ Granger-causes another time series $Y_{t}$ if the latter can be predicted with better accuracy by using past values of $X_{t}$ rather than by not doing so, other information being identical. Testing causal relations between two stationary series $\Delta X_{t}$ and $\Delta Y_{t}$ is based on the following two equations:

$$
\begin{aligned}
\Delta Y_{t} & =\alpha_{0}+\sum_{k=1}^{p} a_{k} \Delta Y_{t-k}+\sum_{k=1}^{p} \beta_{k} \Delta X_{t-k}+\mu_{t} \\
\Delta X_{t} & =\varphi_{0}+\sum_{k=1}^{p} \varphi_{k} \Delta X_{t-k}+\sum_{k=1}^{p} \Phi_{k} \Delta Y_{t-k}+v_{t}
\end{aligned}
$$

Where $\Delta$ is the difference operator, $Y_{t-k}$ and $X_{t-k}$ represent the lagged value of $Y_{t}$ and $X_{t}, \mu_{t}$ and $v_{t}$ are disturbance terms assumed to be white noise. The lag length $(k=1,2, \ldots, p)$ is chosen by using the Akaike information criterion (AIC). The null hypothesis that $X_{t}$ does not Granger cause $Y_{t}$ is not accepted if the $\beta_{k}$ 's $(\mathrm{k}>0)$ are significantly different from zero using standard $\mathrm{F}$ test (the statistic is for the joint hypothesis $\beta_{1}=\beta_{2}=\ldots \ldots=\beta_{\mathrm{k}}=0$ ). Similarly, $Y_{t}$ Granger-causes $X_{t}$ if the $\Phi_{k}$ 's, $\mathrm{k}>0$, are jointly different from zero.

When a research study is based on time series data, it is a prerequisite to check for its stationary properties. A data series is known as a stationary series if its mean and variance are constant over a given period of time and the covariance between the two extreme time periods does not depend on the actual time at which it is computed but it depends only on lag amidst the two extreme time periods. Thereby, this study has examined the stationarity of the above stock indices returns data series most systematically to rule out the likely spurious results. Since testing of the unit-roots of a data series is a precondition to the existence of cointegration relationship and also Granger's (1969) causality test, the ADF (Dickey \& Fuller, 1979; 1981) and PP (1988) tests are used under this study to test the same. In order to test for unit-roots through ADF tests, the following equation is used:

$$
\Delta y_{t}=\alpha_{0}+\lambda y_{t-1}+\sum_{i=1}^{p} \beta_{i} \Delta Y_{t-i}+u_{t}
$$

In the above equation, I have tested the null hypothesis of $\lambda=0$ against the alternative hypothesis of $\lambda<0$. So, the null hypothesis of non-stationarity is rejected if $\lambda$ is negative, and significantly different from zero.

Phillips and Perron (1988) used non-parametric statistical methods to take care of the serial correlation in the error terms without adding lagged difference terms. The test regression for the PP test is the AR (1) process in which the following equation is used:

$$
\Delta Y_{t}=b_{0}+\beta Y_{t-1}+e_{t}
$$

Whether such data is stationary at levels or non-stationary at levels but stationary when differenced, i.e., I(1), determination of the proper multivariate time series analysis technique has to be done. The Vector autoregression (VAR) method requires the variables to be stationary at levels to obtain proper estimates of the coefficients. In empirical applications, the main uses of the VAR are the impulse response analysis, variance decomposition, and Granger causality tests. Impulse response analysis is conducted here to obtain additional insights into the transmitting mechanism (i.e., information transmission) of the stock market movements in the US stock market to the emerging economies especially the Indian stock market and vice versa. The pattern of dynamic responses of each of the seven emerging economies and one rentier stock markets to a shock, i.e., positive residuals of one standard deviation unit in the US stock market, is examined.

To examine the existence of long-run integration between the US and emerging economies markets, Johansen and Juselius's (1990) cointegration technique is used. This technique gives maximum Eigen value and Trace value test statistics for determining the number of cointegrating vectors, i.e., cointegration relationships. In order to fulfill the above objective, the following VECM-specific (i.e., restricted VAR) equation is used:

$$
\Delta x_{t}=A_{0}+\sum_{j=1}^{k-1} \Gamma_{j} \Delta X_{t-j}+\Pi x_{t-k}+\varepsilon_{t}
$$

Where:

$$
\Gamma_{j}=-\sum_{i=j+1}^{k} \mathrm{~A}_{j} \text { and } \Pi=-I+\sum_{i=j+1}^{k} \mathrm{~A}_{j}
$$

The Trace value (Likelihood Ratio [LR]) test statistic is more robust than the maximum Eigen value statistic (Cheung \& Lai, 1993). So, this study has used the former method in order to establish the long-run relationships among the stock markets. Also, if the test statistic is greater than the critical value from the JJ's (1990) tables, I will reject the null hypothesis that there are $r$ cointegrating vectors in favour of the alternative hypothesis under the said test in line with Brooks (2002). 
Most of the previous studies have also used the above mentioned techniques (Arshanapalli et al., 1995; Click \& Plummer, 2005; Wong et al., 2005; Bose \& Mukherjee, 2006; Janor et al., 2007; etc.).

\section{Data and Empirical Results}

This study uses daily closing values for the stock indices of markets in the US, China, India, Indonesia, Philippines, Brazil, Mexico, Turkey, and Russia for the sample period January 1, 2003 to December 31, 2012. The nine benchmark indices used in this study are - S\&P 500 Index (the US), Shanghai Composite Index (China), BSE Sensex (India), Jakarta Composite Index (Indonesia), PSE Composite Index (Philippines), Bovespa Index (Brazil), IPC All-Share Index (Mexico), ISE Istanbul National-100 Index (Turkey), and Russian Trading System (RTS) Index (Russia). All the relevant data is obtained from www.econstats.com, and are denominated in their respective local currency units.

Although daily data captures speedy transmission of information during both short- and long-run dynamic linkages for stock market integration (see Hassan \& Naka, 1996; and Voronkova, 2004), but such data creates the problem of data non-synchronization. Therefore, I have used relevant daily data on which all the nine stock markets were open for trading, and remove the data for the days in which trading was not occurred at least in one market. Thus, data is collected on the same dates across the stock exchanges, and there are 1852 observations in total for each Index series. I have calculated equity returns by taking the natural logarithm of the daily closing price relatives, i.e., $r_{i, t}=\ln \left(P_{i, t} / P_{i, t-1}\right), i=x, y$. Since this study is based on the daily indices closing prices rather than the intra-day prices, it won't add any value by considering the real trading time of different selected exchanges all over the world. The details of the selected international stock indices are summarized in Table 1.

Table 1. Details of international stock indices

\begin{tabular}{llc}
\hline Country & Index & Abbreviation used in this study \\
\hline USA & S\&P 500 Index & SP500 \\
China & Shanghai Composite Index & SHCO \\
India & BSE Sensex & SENSEX \\
Indonesia & Jakarta Composite Index & JACO \\
Philippines & PSE Composite Index & PSE \\
Brazil & Bovespa Index & BOVESPA \\
Mexico & IPC All-Share Index & IPC \\
Turkey & ISE Istanbul National-100 Index & ISE \\
Russia & RTS Index & RTS \\
\hline
\end{tabular}

This study has used graphical presentations (see Fig. 1 and 2), and descriptive statistics results to find out the normality of the indices data series.
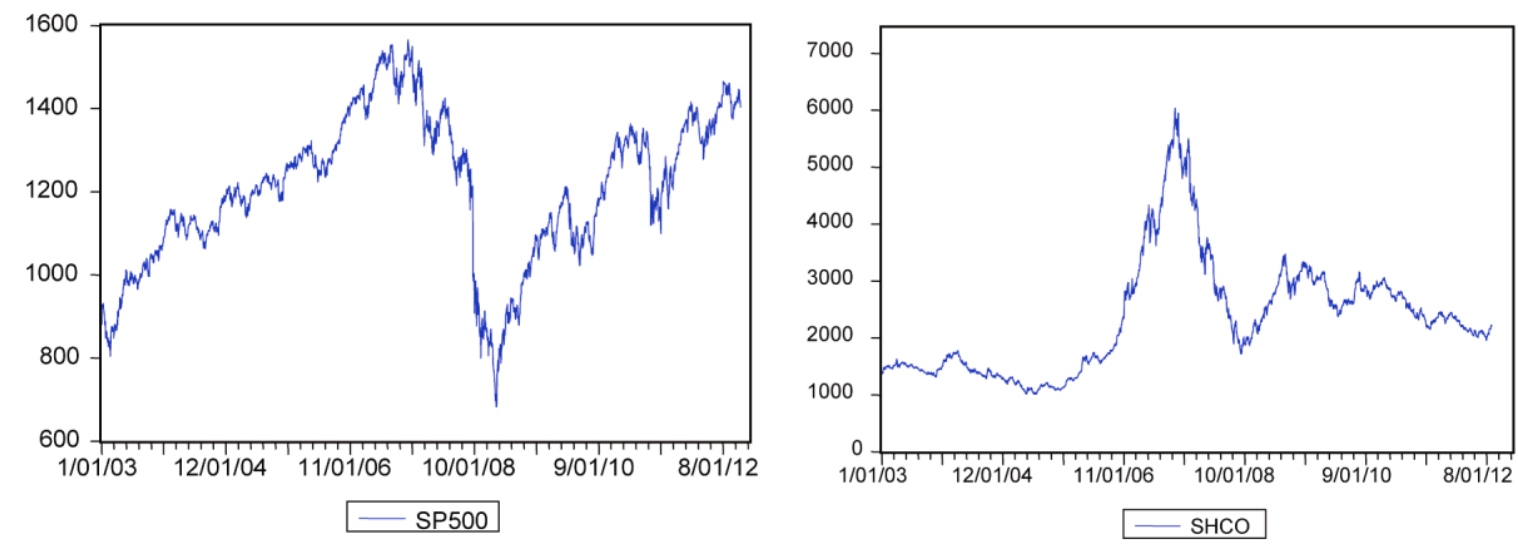

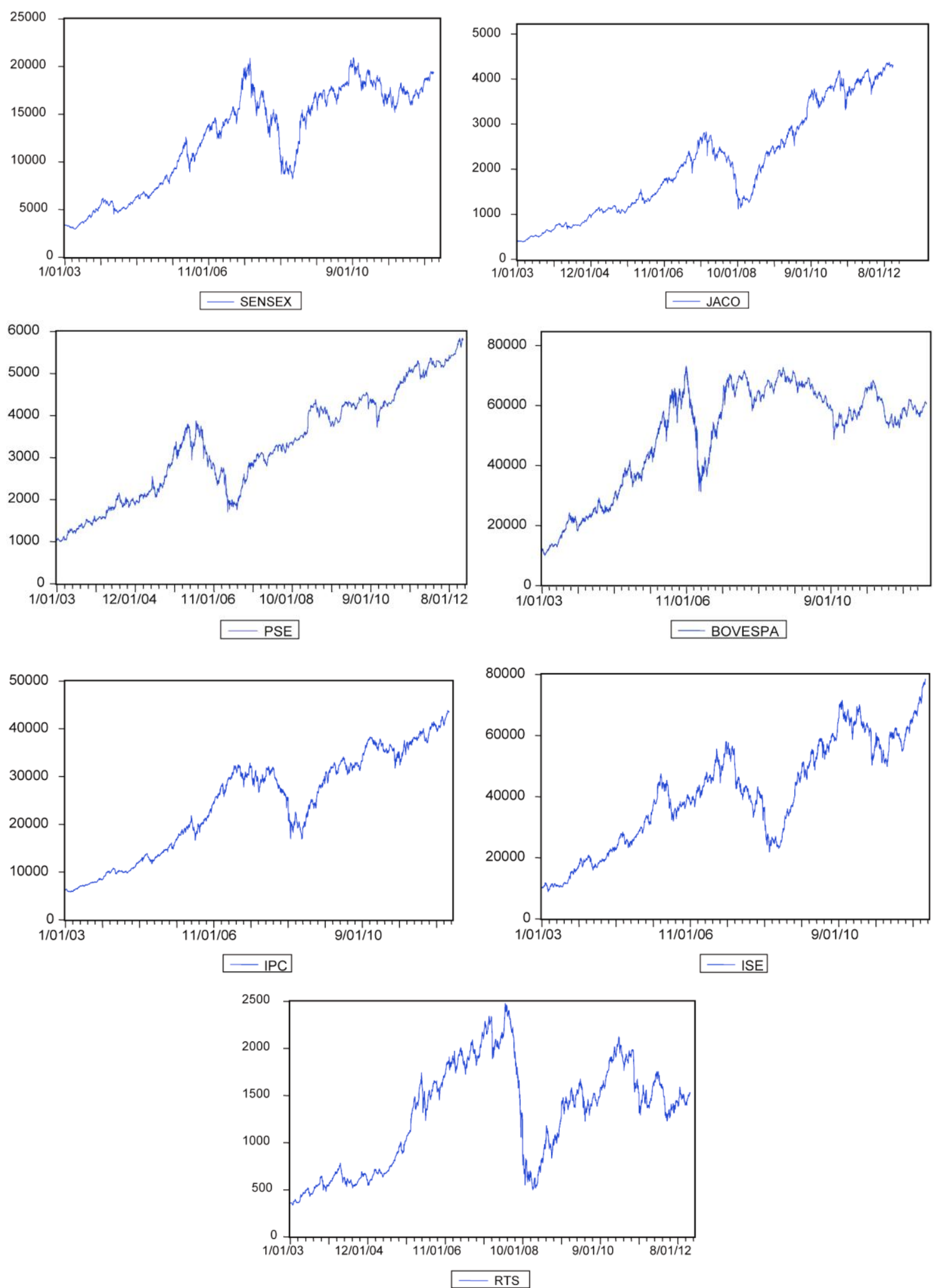

Figure 1. Movement of individual index (Multiple Graphs) ( $1^{\text {st }}$ January, 2003 to $31^{\text {st }}$ December, 2012) 


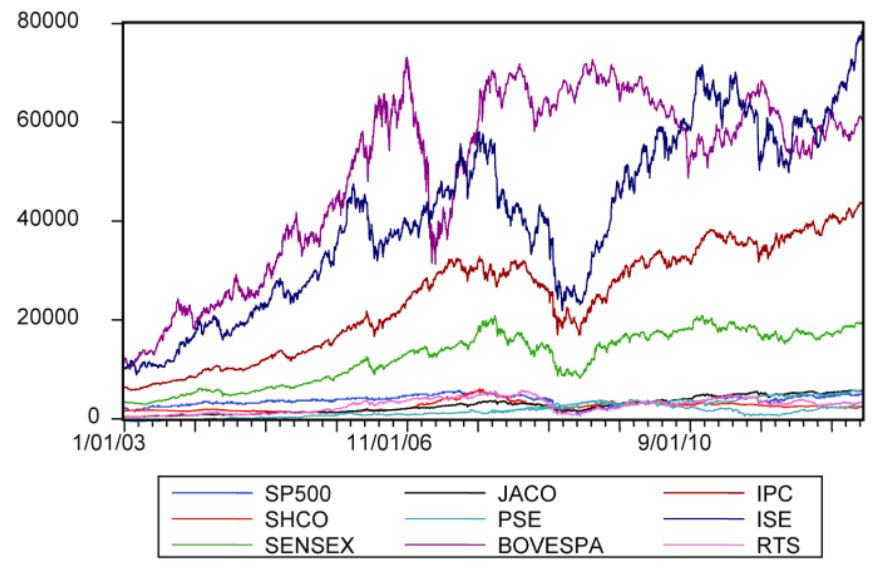

Figure 2. Movements of indices (Single Graph) ( $1^{\text {st }}$ January, 2003 to $31^{\text {st }}$ December, 2012)

A graphical presentation of the closing values of the US and other emerging economies and one rentier indices over the period of this study is given in Figure 1 and in Figure 2 individually. It is seen that the indices are broadly moving together.

Table 2. Descriptive statistics

\begin{tabular}{lccccccccc}
\hline & SP500 & SHCO & SENSEX & JACO & PSE & BOVESPA & IPC & ISE & RTS \\
\hline Mean & 0.000108 & 0.000107 & 0.000409 & 0.000540 & 0.000407 & 0.000394 & 0.000460 & 0.000473 & 0.000339 \\
Median & 0.000395 & 0.000151 & 0.000519 & 0.000622 & 0.000368 & 0.000524 & 0.000689 & 0.000711 & 0.000956 \\
Maximum & 0.040827 & 0.056245 & 0.069444 & 0.053365 & 0.058703 & 0.047630 & 0.044098 & 0.064543 & 0.128236 \\
Minimum & -0.059928 & -0.055431 & -0.055573 & -0.056137 & -0.059237 & -0.081426 & -0.070693 & -0.063627 & -0.171349 \\
Standard Deviation & 0.006114 & 0.008450 & 0.008314 & 0.007692 & 0.007019 & 0.008989 & 0.006658 & 0.009418 & 0.012406 \\
Skewness & -0.683490 & -0.113168 & -0.151798 & -0.690257 & -0.133838 & -0.544730 & -0.551638 & -0.210940 & -1.253062 \\
Kurtosis & 13.59375 & 7.830802 & 10.58161 & 13.44311 & 12.77108 & 10.34598 & 14.67968 & 8.590949 & 35.06690 \\
Jarque-Bera & 8794.910 & 1802.815 & 4437.922 & 8553.506 & 7364.972 & 4251.174 & 10609.15 & 2423.245 & 79747.86 \\
Probability & 0.000000 & 0.000000 & 0.000000 & 0.000000 & 0.000000 & 0.000000 & 0.000000 & 0.000000 & 0.000000 \\
Observations & 1850 & 1850 & 1850 & 1850 & 1850 & 1850 & 1850 & 1850 & 1850 \\
\hline
\end{tabular}

Table 2 gives the summary of descriptive statistics of the index returns of all the selected indices. It is found that all the indices have provided positive average returns during the study period. The differences between max. and min. values do indicate volatility. It is strongly supported by the skewness values for most of the indices. All these point out to the fact that the indices returns don't follow normal distribution. However, standard deviation parameter indicates very less risk in getting returns from the selected markets. The value of kurtosis for all indices returns series has pointed out that they have leptokurtic distribution (i.e., >3) with values concentrated around the mean and thicker tails. This means high probability for extreme values which is observed from the above table. Jarque-Bera test statistic also points out the difference of the skewness and kurtosis of the data series with those from the normal distribution.

This study has also used the ADF and PP tests to find out the stationarity, i.e., whether indices data series contain any unit-root or not.

Table 4 presents the results of ADF and PP tests, i.e., stationary level of all non-stationery indices returns series with intercept and no trend. 
Table 3. Augmented Dickey-Fuller (ADF) and Phillips-Perron (PP) tests with intercept and no trend

\begin{tabular}{|c|c|c|c|c|}
\hline Variables & ADF Results & Conclusion & PP Results & Conclusion \\
\hline SP500 & $-32.69938^{*}$ & $\mathbf{I}(\mathbf{0})$ & $-47.53320^{*}$ & $\mathbf{I}(\mathbf{0})$ \\
\hline SHCO & $-30.06064 *$ & $\mathbf{I}(\mathbf{0})$ & $-43.45222 *$ & $\mathbf{I}(\mathbf{0})$ \\
\hline SENSEX & $-31.44897 *$ & $\mathbf{I}(\mathbf{0})$ & $-42.57512 *$ & $\mathbf{I}(\mathbf{0})$ \\
\hline JACO & $-31.11530^{*}$ & $\mathbf{I}(\mathbf{0})$ & $-41.43564 *$ & $\mathbf{I}(\mathbf{0})$ \\
\hline PSE & $-30.88419^{*}$ & $\mathbf{I}(\mathbf{0})$ & $-41.97673^{*}$ & $\mathbf{I}(\mathbf{0})$ \\
\hline BOVESPA & $-32.62837 *$ & $\mathbf{I}(\mathbf{0})$ & $-42.95785^{*}$ & $\mathbf{I}(\mathbf{0})$ \\
\hline IPC & $-31.45948^{*}$ & $\mathbf{I}(\mathbf{0})$ & $-40.69935^{*}$ & $\mathbf{I}(\mathbf{0})$ \\
\hline ISE & $-30.81916^{*}$ & $\mathbf{I}(\mathbf{0})$ & $-42.92219^{*}$ & $\mathbf{I}(\mathbf{0})$ \\
\hline RTS & $-30.79313 *$ & $\mathbf{I}(\mathbf{0})$ & $-40.61304 *$ & $\mathbf{I}(\mathbf{0})$ \\
\hline \multicolumn{5}{|c|}{$\begin{array}{l}* \text { MacKinnon critical values for rejection of hypothesis (i.e., } \lambda<0 \text { ) of a unit root (at level). } \\
* * \text { MacKinnon critical values for rejection of hypothesis (i.e., } \lambda<0 \text { ) of a unit root (at } 1^{\text {st }} \text { Difference). }\end{array}$} \\
\hline Critical Value at: & $1 \%$ Significance Level & \multicolumn{2}{|c|}{$5 \%$ Significance Level } & $10 \%$ Significance Level \\
\hline ADF Tests (Level) & -3.4369 & \multicolumn{2}{|c|}{-2.8636} & -2.5679 \\
\hline ADF Tests $\left(1^{\text {st }}\right.$ & -3.4369 & \multirow{2}{*}{\multicolumn{2}{|c|}{-2.8636}} & -2.5679 \\
\hline Difference) & & & & \\
\hline PP Tests (Level) & -3.4368 & \multicolumn{2}{|c|}{-2.8636} & -2.5679 \\
\hline PP Tests ( $1^{\text {st }}$ Difference $)$ & -3.4369 & \multicolumn{2}{|c|}{-2.8636} & -2.5679 \\
\hline
\end{tabular}

It is found from the above table that under both ADF and PP tests results all indices returns series of this study have the same order [i.e., I(0)]. So, they are stationary at level and do not contain any unit-roots.

This study uses simple correlation tests results, Granger causality tests results, and VAR results to find out short-run dynamic linkages and integration, and any possible causal relationships in between selected markets in the short-run.

Table 4. Correlations results

\begin{tabular}{crrrrrrrrr}
\hline & \multicolumn{1}{c}{ SP500 } & \multicolumn{1}{c}{ SHCO } & SENSEX & \multicolumn{1}{c}{ JACO } & \multicolumn{1}{c}{ PSE } & \multicolumn{1}{c}{ BOVESPA } & \multicolumn{1}{c}{ IPC } & \multicolumn{1}{c}{ ISE } & \multicolumn{1}{c}{ RTS } \\
\hline SP500 & 1.000000 & 0.083876 & 0.283663 & .211120 & 0.119977 & $\mathbf{0 . 7 1 6 1 5 3}$ & $\mathbf{0 . 7 4 1 6 2 8}$ & .351248 & .416978 \\
SHCO & .083876 & .000000 & 0.221812 & 0.244631 & .178603 & 0.192036 & 0.160099 & .140597 & .196880 \\
SENSEX & .283663 & 0.221812 & 1.000000 & $\mathbf{. 5 0 9 6 2 3}$ & 0.309865 & 0.363142 & .363370 & 0.412866 & .460487 \\
JACO & .211120 & 0.244631 & $\mathbf{0 . 5 0 9 6 2 3}$ & .000000 & .499088 & 0.336053 & .309373 & .373703 & 0.461374 \\
PSE & .119977 & 0.178603 & 0.309865 & .499088 & .000000 & 0.245711 & .202597 & 0.318773 & 0.321024 \\
BOVESPA & $\mathbf{0 . 7 1 6 1 5 3}$ & 0.192036 & 0.363142 & .336053 & .245711 & 1.000000 & $\mathbf{. 7 1 8 8 0 5}$ & 0.417726 & $\mathbf{0 . 5 0 7 3 5 1}$ \\
IPC & $\mathbf{. 7 4 1 6 2 8}$ & .160099 & 0.363370 & 0.309373 & 0.202597 & $\mathbf{0 . 7 1 8 8 0 5}$ & .000000 & 0.403124 & $\mathbf{0 . 5 0 1 5 4 0}$ \\
ISE & .351248 & .140597 & 0.412866 & .373703 & .318773 & 0.417726 & 0.403124 & 1.000000 & $\mathbf{0 . 5 3 0 2 2 4}$ \\
RTS & .416978 & 0.196880 & 0.460487 & 0.461374 & 0.321024 & $\mathbf{0 . 5 0 7 3 5 1}$ & $\mathbf{0 . 5 0 1 5 4 0}$ & $\mathbf{. 5 3 0 2 2 4}$ & 1.000000 \\
\hline
\end{tabular}

Table 4 (Karl Pearson's correlation among various indices) tabulates the cross-correlation matrix showing the correlation coefficients between S\&P 500 Index (i.e., the US stock market) and other indices. It is found that SP500 has a positive and strong correlationship with the Brazilian (i.e., 0.716153) and Mexico (i.e., 0.741628) stock markets. With all other markets, the US stock market has a positive relationship. It is also observed from Table 4 that the BSE Sensex has also have positive relationships with all other emerging economies and one rentier, i.e., Russia, but, except Indonesia (with correlation coefficient of $\mathbf{0 . 5 0 9 6 2 3}$ ) it does not have very significant relationships. The BOVESPA Index has shown strong and significant positive correlation with the Mexican (i.e., $\mathbf{0 . 7 1 8 8 0 5}$ ), and also with the RTS Index (with correlation coefficient of $\mathbf{0 . 5 0 7 3 5 1}$ ). This study has also found significant positive correlation in between IPC-RTS (i.e., 0.501540), and ISE-RTS (i.e., 0.530224). In regard to the Indian stock market, it is worthy to mention here is that medium strong correlationship is observed along with most of the studied markets. It is also observed that the American continent stock markets are mostly correlated than their Asian counterparts. 
Table 5. Akaike Information Criteria (AIC)

\begin{tabular}{cc}
\hline AIC Value & Lag \\
\hline 60038.61 & $(11)$ \\
60054.16 & $(1)$ \\
60062.94 & $(13)$ \\
\hline
\end{tabular}

Note. This criteria is used to determine the lag length - the smaller the value of the information criteria, the 'better' the model is.

This study has applied Granger causality test of Granger (1969) with 1 lag (see Table 5).

Table 6. Granger causality test results

\begin{tabular}{|c|c|c|c|}
\hline Null Hypothesis: & Observations & F-statistic & Probability \\
\hline SHCO does not Granger Cause SP500 & 1851 & 0.74009 & 0.38974 \\
\hline SP500 does not Granger Cause SHCO & & 28.8154 & $9.0 \mathrm{E}-08$ \\
\hline SENSEX does not Granger Cause SP500 & 1851 & 0.19540 & 0.65851 \\
\hline SP500 does not Granger Cause SENSEX & & 142.647 & 0.00000 \\
\hline JACO does not Granger Cause SP500 & 1851 & 4.33924 & 0.03738 \\
\hline SP500 does not Granger Cause JACO & & 215.112 & 0.00000 \\
\hline PSE does not Granger Cause SP500 & 1848 & 3.34113 & 0.06773 \\
\hline SP500 does not Granger Cause PSE & & 297.421 & 0.00000 \\
\hline BOVESPA does not Granger Cause SP500 & 1848 & 0.03243 & 0.85712 \\
\hline SP500 does not Granger Cause BOVESPA & & 4.58347 & 0.03241 \\
\hline IPC does not Granger Cause SP500 & 1851 & 0.73892 & 0.39012 \\
\hline SP500 does not Granger Cause IPC & & 0.15422 & 0.69458 \\
\hline ISE does not Granger Cause SP500 & 1851 & 2.31811 & 0.12805 \\
\hline SP500 does not Granger Cause ISE & & 58.8754 & $2.7 \mathrm{E}-14$ \\
\hline RTS does not Granger Cause SP500 & 1851 & 2.72080 & 0.09922 \\
\hline SP500 does not Granger Cause RTS & & 112.872 & 0.00000 \\
\hline SENSEX does not Granger Cause SHCO & 1851 & 6.72760 & 0.00957 \\
\hline SHCO does not Granger Cause SENSEX & & 0.04905 & 0.82475 \\
\hline JACO does not Granger Cause SHCO & 1851 & 0.55365 & 0.45692 \\
\hline SHCO does not Granger Cause JACO & & 0.49004 & 0.48400 \\
\hline PSE does not Granger Cause SHCO & 1848 & 0.02864 & 0.86562 \\
\hline SHCO does not Granger Cause PSE & & 4.51847 & 0.03366 \\
\hline BOVESPA does not Granger Cause SHCO & 1848 & 20.0821 & 7.9E-06 \\
\hline SHCO does not Granger Cause BOVESPA & & 0.23133 & 0.63060 \\
\hline IPC does not Granger Cause SHCO & 1851 & 18.1208 & $2.2 \mathrm{E}-05$ \\
\hline SHCO does not Granger Cause IPC & & 1.07493 & 0.29997 \\
\hline ISE does not Granger Cause SHCO & 1851 & 5.92546 & 0.01502 \\
\hline SHCO does not Granger Cause ISE & & 0.07682 & 0.78169 \\
\hline RTS does not Granger Cause SHCO & 1851 & 6.53917 & 0.01063 \\
\hline SHCO does not Granger Cause RTS & & 0.06148 & 0.80420 \\
\hline JACO does not Granger Cause SENSEX & 1851 & 0.26328 & 0.60794 \\
\hline SENSEX does not Granger Cause JACO & & 24.2866 & $9.0 \mathrm{E}-07$ \\
\hline PSE does not Granger Cause SENSEX & 1848 & 0.01755 & 0.89462 \\
\hline SENSEX does not Granger Cause PSE & & 75.1729 & 0.00000 \\
\hline BOVESPA does not Granger Cause SENSEX & 1848 & 74.3612 & 0.00000 \\
\hline SENSEX does not Granger Cause BOVESPA & & 0.18522 & 0.66697 \\
\hline IPC does not Granger Cause SENSEX & 1851 & 122.355 & 0.00000 \\
\hline SENSEX does not Granger Cause IPC & & 0.22450 & 0.63569 \\
\hline ISE does not Granger Cause SENSEX & 1851 & 10.3286 & 0.00133 \\
\hline SENSEX does not Granger Cause ISE & & 11.7528 & 0.00062 \\
\hline RTS does not Granger Cause SENSEX & 1851 & 7.14168 & 0.00760 \\
\hline SENSEX does not Granger Cause RTS & & 9.10741 & 0.00258 \\
\hline PSE does not Granger Cause JACO & 1848 & 1.39068 & 0.23844 \\
\hline
\end{tabular}




\begin{tabular}{|c|c|c|c|}
\hline JACO does not Granger Cause PSE & & 31.9568 & $1.8 \mathrm{E}-08$ \\
\hline BOVESPA does not Granger Cause JACO & 1848 & 179.990 & 0.00000 \\
\hline JACO does not Granger Cause BOVESPA & & 5.26437 & 0.02188 \\
\hline IPC does not Granger Cause JACO & 1851 & 179.535 & 0.00000 \\
\hline JACO does not Granger Cause IPC & & 12.4316 & 0.00043 \\
\hline ISE does not Granger Cause JACO & 1851 & 11.8777 & 0.00058 \\
\hline JACO does not Granger Cause ISE & & 2.30467 & 0.12916 \\
\hline RTS does not Granger Cause JACO & 1851 & 30.0194 & 4.9E- 08 \\
\hline JACO does not Granger Cause RTS & & 0.22999 & 0.63159 \\
\hline BOVESPA does not Granger Cause PSE & 1848 & 236.822 & 0.00000 \\
\hline PSE does not Granger Cause BOVESPA & & 6.67028 & 0.00988 \\
\hline IPC does not Granger Cause PSE & 1848 & 282.916 & 0.00000 \\
\hline PSE does not Granger Cause IPC & & 10.8632 & 0.00100 \\
\hline ISE does not Granger Cause PSE & 1848 & 51.8848 & $8.5 \mathrm{E}-13$ \\
\hline PSE does not Granger Cause ISE & & 0.10092 & 0.75077 \\
\hline RTS does not Granger Cause PSE & 1848 & 68.6870 & 2.2E-16 \\
\hline PSE does not Granger Cause RTS & & 7.79770 & 0.00529 \\
\hline IPC does not Granger Cause BOVESPA & 1848 & 2.14541 & 0.14317 \\
\hline BOVESPA does not Granger Cause IPC & & 0.82282 & 0.36448 \\
\hline ISE does not Granger Cause BOVESPA & 1848 & 2.14059 & 0.14362 \\
\hline BOVESPA does not Granger Cause ISE & & 52.6270 & $5.9 \mathrm{E}-13$ \\
\hline RTS does not Granger Cause BOVESPA & 1848 & 2.46846 & 0.11632 \\
\hline BOVESPA does not Granger Cause RTS & & 90.6568 & 0.00000 \\
\hline ISE does not Granger Cause IPC & 1851 & 1.24119 & 0.26539 \\
\hline IPC does not Granger Cause ISE & & 61.4581 & 7.6E-15 \\
\hline RTS does not Granger Cause IPC & 1851 & 6.97775 & 0.00832 \\
\hline IPC does not Granger Cause RTS & & 99.2305 & 0.00000 \\
\hline RTS does not Granger Cause ISE & 1851 & 0.23831 & 0.62549 \\
\hline ISE does not Granger Cause RTS & & 0.33495 & 0.56283 \\
\hline
\end{tabular}

Table 6 presents the Granger causality tests results for this study. The results show no short-run causal relationships in between SP500 and SHCO, BOVESPA, IPC, and also with ISE. Similarly, no unidirectional or bidirectional causal relationship is found in between China-Indonesia, China-Philippines, China-Brazil, China-Mexico, China-Turkey, and China-Russia stock markets. India, Philippines, and Russian stock markets also don't have any short-run causal relationships. No relationship is also found in the short-run in PSE-ISE, IPC-BOVESPA, ISE-BOVESPA, ISE-IPC, and RTS-ISE. However, many of the above results are in contradiction with the earlier correlation results (see Table 3) where significant positive relationships have been found in these international stock indices returns.

However, some interesting findings are observed under this study from the above Granger causality tests results. The Indian stock market represented by the BSE Sensex Index has shown bidirectional short-run relationship with the Turkish stock market. Also, it has shown bidirectional causality with the Russian stock market represented by the RTS Index. Another very interesting observation as found from the results is that the Mexican and Indonesian stock market Granger causes each other. Similar bidirectional causality is also observed in between BOVESPA-PSE, IPC-PSE, and RTS-IPC. Such relationships are also unique keeping in mind their diverse settings in all regards. So, it is found that the Philippines stock market is the most causally-linked with the international markets among the ASEAN markets.

It is also found that SP500 Granger causes the BSE Sensex returns, i.e., the Indian stock market, the Indonesian stock market, the Philippines stock market, and also the RTS Index returns (i.e., the Russian stock market). Thus, as the empirical literature put the US as the leading stock market and a catalyst in influencing the international stock markets (see, e.g., Eun \& Shim, 1989; Hamao et al., 1990; Becker et al., 1990; Cheung \& Mak, 1992; Masih \& Masih, 1997; 1999; 2002; Liu et al., 1998; Chan, 2002; etc.), this study has proved the same at least in the short-run.

This study has also found that the BSE Sensex Granger causes the Chinese stock market returns, and the Philippines PSE Index. However, it is observed that BOVESPA (Brazil), and IPC (Mexico) Granger causes the Indian stock market returns. Thus, it is evident that the Indian stock market does have short-run relationships 
with its BRIC counterparts and some other international markets including the US market.

Apart from this, BOVESPA, and ISE Granger causes the Indonesian stock market returns. Also, the Philippines stock market returns have a unidirectional relationship with the RTS Index, and BOVESPA Granger causes the Russian stock market returns in the short-run.

Overall, this study has found twelve unidirectional and six bidirectional Granger causality effect in between the US and emerging economies and one rentier stock markets.

The pattern of dynamic responses of each of the selected stock markets to a shock, i.e., positive residuals of one standard deviation unit in all other stock markets, has been examined first. Fig. 3 has presented the results.
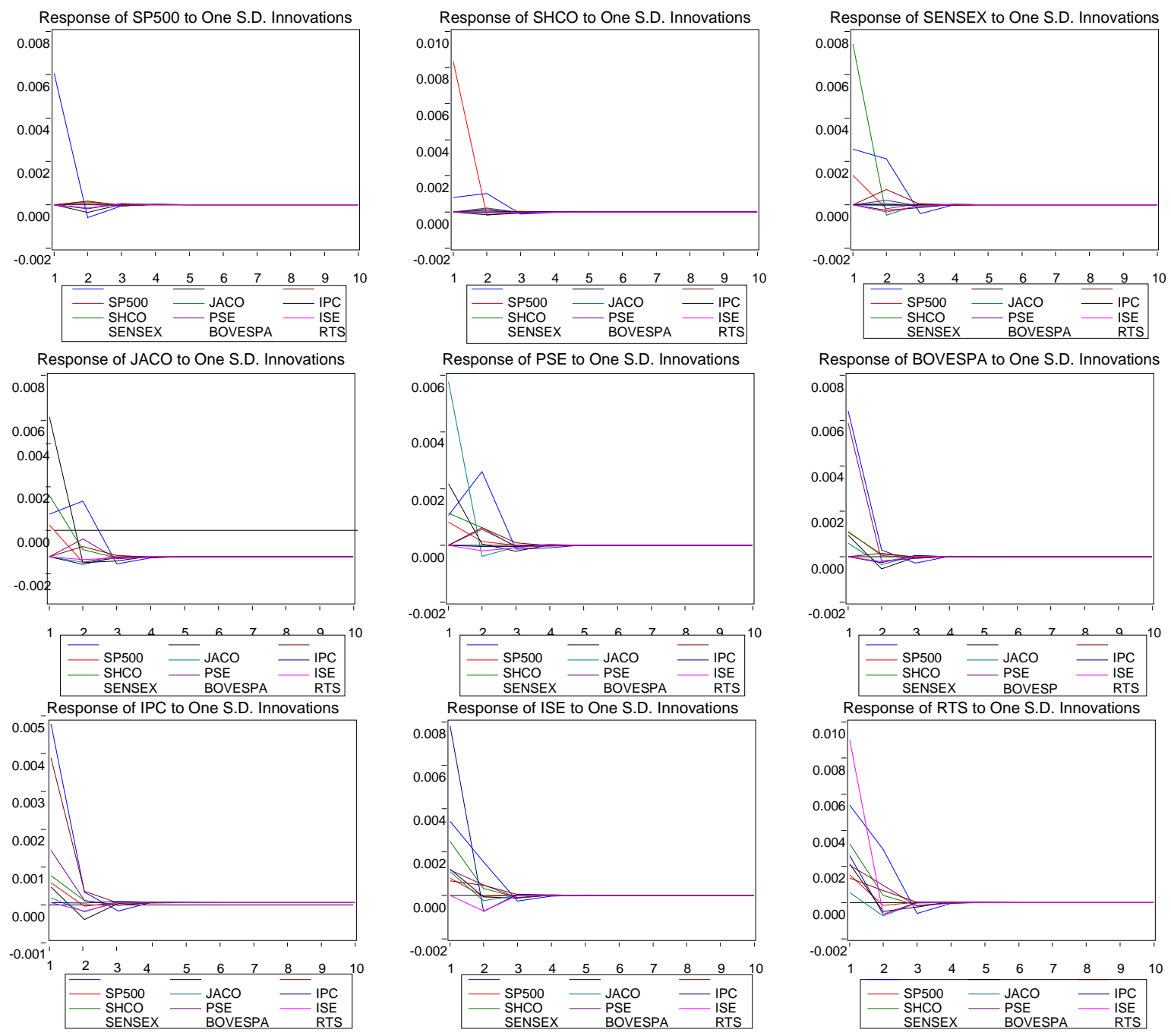

Figure 3. Response of US and other indices to One S.D. innovations

It is worth mentioning here that a different ordering of the variables in the system may provide different results for Choleski decomposition of the innovation matrix, so the arbitrariness of the ordering can be subject to criticism. In this study, the causal ordering of the variables is SP500, SHCO, SENSEX, JACO, PSE, BOVESPA, IPC, ISE, and RTS.

Figure 4 and 5 provide plots of the time paths of the impulse responses for these nine stock markets to a market shock (i.e., in the US market) during the study period (Figure 4), and also impulse responses of SP500 to the corresponding market shock in other international markets (Figure 5) at the finest time scale (d1). In Figure 4, the solid line plots the point estimates of the impulse responses of the stock market indices to standard deviation shocks of the SP500. In Figure 5, the solid line plots the point estimates of the impulse responses of the US stock 
market index, i.e., the S\&P 500 Index to standard deviation shocks of the international stock indices. The dotted lines in both the figures are the two standard deviation bands around the points estimates.

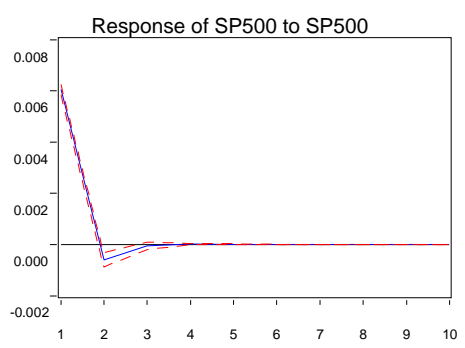

Response to One S.D. Innovations \pm 2 S.E.
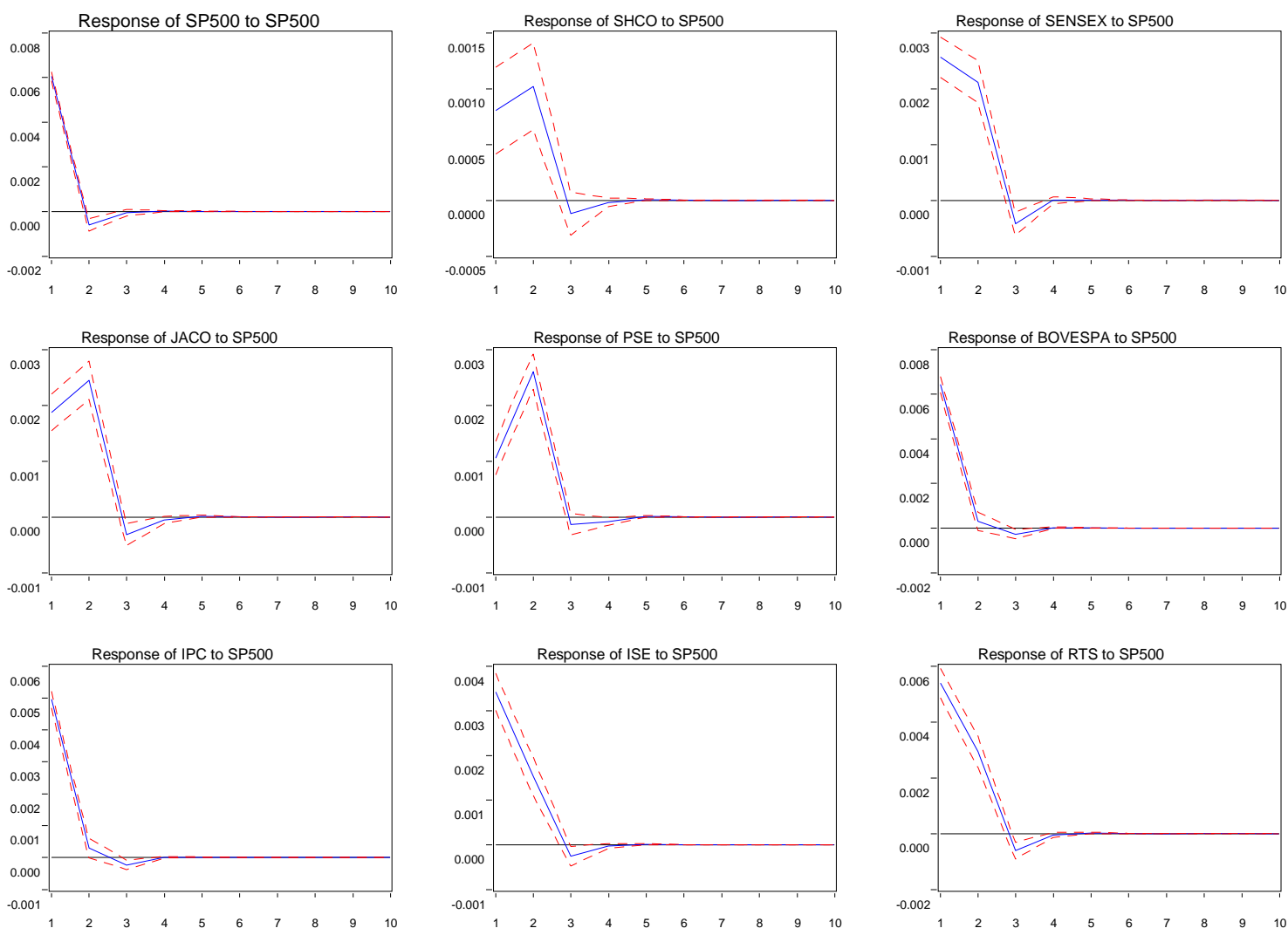

Figure 4. Response to one S.D. Innovations \pm 2 S.E. 




Response to One S.D. Innovations \pm 2 S.E.
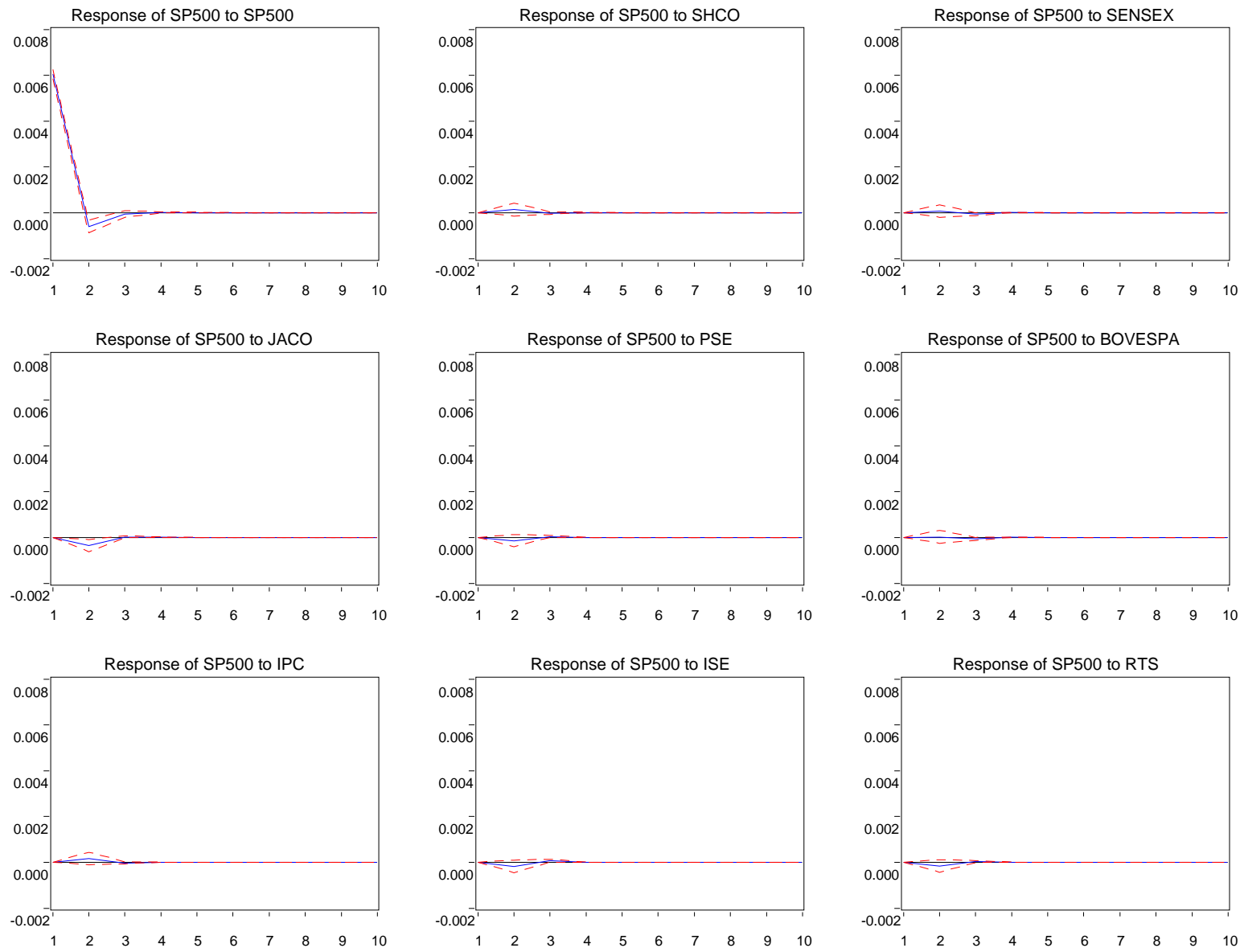

Figure 5. Response to one S.D. innovations \pm 2 S.E.

In the short-run, the dynamic linkages of the US and other international stock indices are quite clear from the above figures. A positive one standard deviation shock to the US stock market Index has negative impact on most other markets including the Indian, Brazilian, Mexican, Turkish, and Russian stock markets in the short-run. The other markets are however showing positive response in the first two days at least. A mild dynamic response has also observed in case of the S\&P 500 Index to other international markets. Thus, the dynamic linkages of above-selected individual markets with the US market are evident for the short-run.

After an in-depth study to find short-run relationships and dynamic linkages of these stock markets, this study reveals the long-run integration in between these markets.

In multivariate co-integration analysis using $\mathrm{JJ}$ technique, the first step is the appropriate lag selection for the variables. Here one lag length has been selected on the basis of AIC (see Table 5).

Under JJ tests, test statistics are calculated allowing for an intercept and no trend term in the cointegrating equation (CE) and test the VAR.

Table 7. Results of JJ Cointegration test

Likelihood Ratio (Trace) test for cointegrating rank

\begin{tabular}{cccccc}
\hline Variable & Eigenvalue & $\begin{array}{c}\text { Likelihood Ratio } \\
(\mathrm{LR})\end{array}$ & $\begin{array}{c}5 \% \\
\text { Critical Value }\end{array}$ & $\begin{array}{c}1 \% \\
\text { Critical Value }\end{array}$ & $\begin{array}{c}\text { Hypothesized } \\
\text { No. of CE(s) }\end{array}$ \\
\hline SP500 & 0.456761 & 7642.574 & 192.89 & 205.95 & None ** \\
SHCO & 0.421951 & 6516.133 & 156.00 & 168.36 & At most 1 ** \\
SENSEX & 0.397515 & 5504.348 & 124.24 & 133.57 & At most 2 ** \\
\hline
\end{tabular}




\begin{tabular}{|c|c|c|c|c|c|}
\hline JACO & 0.364698 & 4568.995 & 94.15 & 103.18 & At most $3 * *$ \\
\hline PSE & 0.358874 & 3731.549 & 68.52 & 76.07 & At most $4 * *$ \\
\hline BOVESPA & 0.348705 & 2910.948 & 47.21 & 54.46 & At most $5 * *$ \\
\hline IPC & 0.334948 & 2119.396 & 29.68 & 35.65 & At most $6 * *$ \\
\hline ISE & 0.318235 & 1366.432 & 15.41 & 20.04 & At most $7 * *$ \\
\hline RTS & 0.300327 & 659.2854 & 3.76 & 6.65 & At most $8 * *$ \\
\hline
\end{tabular}

$*(* *)$ denotes rejection of the hypothesis at $5 \%(1 \%)$ significance level.

L.R. test indicates 9 cointegrating equation(s) at 5\% significance level.

The results of the Johansen and Juselius's Trace test are shown in Table 7. At the 5\% significance level the Trace test suggests that the indices are cointegrated with $r>8$. It implies that there are at least nine cointegration vectors, i.e., nine CEs in order to establish long-run relationships among the stock markets. Thus, the long-run relationships among these stock markets are overwhelmingly established. So, it is evident that the US stock market is closely integrated and interdependent with these emerging economies and one rentier international stock markets. However, these results are in contrast with the earlier correlation results (see Table 4), and the short-run Granger causality tests results. This also nullifies any chance of long-run portfolio diversification opportunities for the US and other investors in these emerging economies and one rentier stock markets.

\section{Conclusion}

This study has investigated the integration, and dynamic linkages of the US stock market with the emerging economies and one rentier stock markets with special reference to India. The indices returns series for ten years (2003-12) at a stretch is undertaken.

The Jarque-Bera test has pointed out non-normality of the indices returns series. Thus, the ADF and PP tests are conducted. These results point out that the data is stationary at level [i.e., I(0)]. Based on the results, short-run relationships and dynamic linkages are found by using correlation tests results, Granger causality tests results, and impulse responses. Correlation tests result indicate significant relationships in between the American markets. However, the Indian stock market has shown a strong positive correlation with only one of its ASEAN counterpart, i.e., Indonesia. No other short-run relationship is found with any other emerging economies stock markets, neither with the US market.

The Granger causality tests results have found many bi- and uni-directional causal relationships in between these markets. The US causal influence is mostly observed. The Indian stock market has a strong granger causality effect in the short-run over the Chinese and Philippines stock markets. In an interesting finding, it is also observed that the BSE Sensex returns and the ISE National-100 Index returns strongly influencing each other in the short-run. The Russian and the Indian stock markets are also showing bidirectional Granger causality. But, mostly these results are not in line with the correlation results. The IRF results also have shown dynamic linkages of the US stock market with most of these markets in the short-run. In the long-run, JJ co-integration tests results show nine pairs of co-integrating relationships in between these markets. So, long-run integration and interdependence among these emerging economies and one rentier, and the US stock market has been proved under this study. These results are mostly in line with the earlier results from the studies of Bose (2005), Dunis and Shannon (2005), Chen et al. (2006), and Chittedi (2009), etc., but in contrast with An and Brown (2010).

It can also be concluded that these emerging economies and one rentier stock markets are not at all the most favourable destinations for the US and other global investors in the coming future, at least in the long-run. However, in the short-run among these markets, the Chinese and Brazilian stock markets can become the most profitable portfolio diversification opportunities for the US investors.

This study is not free from limitations. It didn't take into consideration the impact of sub-prime crisis that caused havoc throughout the world during this study period. Also, the application of price-based measure to measure international stock markets integration is a limiting factor for this study. There are serious practical problems in employing prices to measure global or regional integration, particularly in emerging markets. This is because such prices may move in tandem because of a common external factor or because of similar macroeconomic fundamentals, and not because of market cointegration or linkages. Moreover, prices may be affected by differences in currency, credit and liquidity risks, implying different price movements even if there is a substantial degree of financial integration (Prasad et al., 2006).

Future studies should also take into consideration the integrating role of other developed countries, like the UK, Germany, Japan, etc. or other developing regions like the MENA, SAARC, etc. on these emerging economies 
stock markets with the similar kinds of returns data series. Also, macroeconomic analysis should be included in these kinds of studies to make the results more authentic and reliable.

\section{References}

Agarwal, R. N. (2000). Capital Market Development, Corporate Financing Pattern and Economic Growth in India. Institute of Economic Growth Discussion Papers, No. 20.

Agmon, T. (1972). The relations among equity markets: A study of share price co-movements in the United States, United Kingdom, Germany and Japan. The Journal of Finance, 27(4), 839-855. http://dx.doi.org/10.1111/j.1540-6261.1972.tb01315.x

Aktar, I. (2009). Is there any Comovement Between Stock Markets of Turkey, Russia and Hungary? International Research Journal of Finance and Economics, 26, 192-200.

An, L., \& Brown, D. (2010). Equity Market Integration between the US and BRIC Countries: Evidence from Unit Root and Cointegration Test. Research Journal of International Studies, 16, 15-24.

Arshanapalli, B., \& Kulkarni, M. S. (2001). Interrelationship between Indian and US Stock Markets. Journal of Management Research, 1.

Arshanapalli, B., Doukas, J., \& Lang, L. H. P. (1995). Pre and post October 1987 stock market linkages between US and Asian markets. Pacific Basin Finance Journal, 3, 57-73. http://dx.doi.org/10.1016/0927-538X(94)00025-3

Awokuse, T. O., Chopra, A., \& Bessler, D. A. (2009). Structural change and international stock market interdependence: Evidence from Asian emerging markets. Economic Modeling, 26. http://dx.doi.org/10.1016/j.econmod.2008.12.001

Becker, K. G., Finnerty, J. E., \& Gupta, M. (1990). The intertemporal relation between the US and Japanese stock markets. The Journal of Finance, 45, 1297-1306.

Bekaert, G., Harvey, C. R., \& Lumsdaine, R. L. (2002). Dating the integration of the world equity markets. Journal of Financial Economics, 65, 203-247. http://dx.doi.org/10.1016/S0304-405X(02)00139-3

Bensidoun, I., Lemoine, F., \& Ünal, D. (2009). The integration of China and India into the world economy: A comparison. The European Journal of Comparative Economics, 6(1), 131-155.

Bhar, R., \& Nikolova, B. (2009). Return, Volatility Spillovers and Dynamic Correlation in the Bric Equity Markets: An Analysis Using a Bivariate Egarch Framework. Global Finance Journal, 19, 203-218. http://dx.doi.org/10.1016/j.gfj.2008.09.005

Bose, S. (2005). Indian, US and Asian Stock Markets Recent Trends in Interlink Ages. ICRA Bulletin, 2, 49-66.

Bose, S., \& Mukherjee, P. (2006). A study of interlinkages between the Indian stock market and some other emerging and developed markets. Paper presented at the 9th Capital Markets Conference, Indian Institute of Capital Markets, Mumbai, India.

Brooks, C. (2002). Introductory Econometrics for Finance (1st ed.). London: Cambridge University Press.

Chan, W. S. (2002). Stock Price Reaction to News and No-News: Drift and Reversal After Headlines. M.I.T. Sloan School of Management, Working Paper.

Chen, H., Lobo, J. B., \& Wong, W. K. (2006). Links between the Indian, US and Chinese Stock Markets. Working Paper, No. 0602.

Cheung, Y. L., \& Mak, S. C. (1992). The international transmission of stock market fluctuation between the developed markets and the Asian-Pacific markets. Applied Financial Economics, 2(1), 43-47. http://dx.doi.org/10.1080/758527545

Cheung, Y. W., \& Lai, K. (1993). A fractional cointegration analysis of purchasing power parity. Journal of Business \& Economic Statistics, 11, 103-112.

Chittedi, K. R. (2009). Global Stock Market Development and Integration: With Special Reference to BRIC Countries. Muniche Personal Repec Archive, 3-21.

Choudhry, T. (1997). Stochastic Trends in Stock Prices: Evidence from Latin American Markets. Journal of Macroeconomics, 19(2), 285-304. http://dx.doi.org/10.1016/S0164-0704(97)00016-5

Click, R. W., \& Plummer, M. G. (2005). Stock market integration in ASEAN after the Asian financial crisis. Journal of Asian Economics, 16, 5-28. http://dx.doi.org/10.1016/j.asieco.2004.11.018 
Dasgupta, R. (2013). India's Integration and Dynamic Linkages with World Emerging Economies and the US Opportunities for Portfolio Diversification. International Research Journal of Finance and Economics, 117, 225-245.

Dasgupta, R. (2014). Integration and Dynamic Linkages of the Indian Stock Market with BRIC - An Empirical Study. Asian Economic and Financial Review, 4(6), 715-731.

Dickey, D. A., \& Fuller, W. A. (1979). Distributions of the Estimators for Autoregressive Time Series with a Unit Root. Journal of American Statistical Association, 74(366), 427-481. http://dx.doi.org/10.2307/2286348

Dickey, D. A., \& Fuller, W. A. (1981). Likelihood ratio statistics for autoregressive time series with a unit root. Econometrica, 49, 1057-1072. http://dx.doi.org/10.2307/1912517

Dunis, C. L., \& Shannon, G. (2005). Emerging markets of South-East and Central Asia: Do they still offer a diversification benefit?. Journal of Asset Management, 6(3), 168-190. http://dx.doi.org/10.1057/palgrave.jam.2240174

Erbaykal, E., Okuyan, H. A., \& Kadığlu, O. (2008). Cointegration and Priority Relationships between Stock Markets of Turkey, Brazil and Argentina. European Journal of Economics, Finance and Administrative Sciences, 10, 151-158.

Eun, C., \& Shim, S. (1989). International transmission of stock market movements. Journal of Financial and Quantitative Analysis, 24, 241-256. http://dx.doi.org/10.2307/2330774

Ghosh, A., Saidi, R., \& Johnson, K. H. (1999). Who Moves the Asia-Pacific Stock Markets-Japan or US? Empirical Evidence Based on the Theory of Cointegration. Financial Review, 34, 159-170. http://dx.doi.org/10.1111/j.1540-6288.1999.tb00450.x

Grubel, H. (1968). Internationally diversified portfolios: Welfare gains and capital flows. The American Economic Review, 58, 1299-1314.

Hamao, Y. R., Masulis, R. W., \& Ng, V. K. (1990). Correlations in Price Changes and Volatility across International Stock Markets. Review of Financial Studies, 3(1), 281-307. http://dx.doi.org/10.1093/rfs/3.2.281

Hassan, M. K., \& Naka, A. (1996). Short-run and long-run dynamic linkages among international stock markets. International Review of Economics and Finance, 5(1). http://dx.doi.org/10.1016/S1059-0560(96)90025-8

Hilliard, J. (1979). The relationship between equity indices on world exchanges. The Journal of Finance, 34, 103-114. http://dx.doi.org/10.1111/j.1540-6261.1979.tb02074.x

Ignatius, R. (1992). The Bombay Stock Exchange: Seasonalities and Investment Opportunities. Indian Economic Review, 27(2), 223-227.

Janor, H., Ali, R., \& Shaharudin, R. S. (2007). Financial integration through equity markets and the role of exchange rate: Evidence from ASEAN-5 countries. Asian Academy of Management Journal of Accounting and Finance, 3(1), 77-92.

Johansen, S., \& Juselius, K. (1990). Maximum Likelihood Estimation and Inference on Cointegration- With Applications to the Demand For Money. Oxford Bulletin of Economics and Statistics, 52(2), 169-210. http://dx.doi.org/10.1111/j.1468-0084.1990.mp52002003.x

Kearney, C., \& Lucey, B. M. (2004). International equity market integration: Theory, evidence and implications. International Review of Financial Analysis, 13, 571-583. http://dx.doi.org/10.1016/j.irfa.2004.02.013

Leong, S. C., \& Felmingham, B. (2001). The interdependence of share markets in the developed economies of East Asia. Pacific-Basin Finance Journal, 11, 219-237. http://dx.doi.org/10.1016/S0927-538X(03)00002-7

Liu, Y. A., Pan, M. S., \& Shieh, J. (1998). International transmission of stock price movements: Evidence from the U.S. and five Asian-Pacific markets. Journal of Economics and Finance, 22(1), 59-69. http://dx.doi.org/10.1007/BF02823233

Majid, M. S. A., Meera, A. K. M., Omar, M. A., \& Aziz, H. A. (2009). Dynamic Linkages Among ASEAN-5 Emerging Stock Markets. International Journal of Emerging Markets, 4(2).

Markowitz, H. (1952). Portfolio selection. Journal of Finance, 7, 77-91. http://dx.doi.org/10.1111/j.1540-6261.1952.tb01525.x

Masih, A. M., \& Masih, R. (1997). Dynamic Linkages and Propagation Mechanism Driving Major International Stock Markets: An Analysis of the Pre and Post Crash Eras. Quarterly Review of Economics and Finance, 


\section{7, 859-885. http://dx.doi.org/10.1016/S1062-9769(97)90008-9}

Masih, A. M., \& Masih, R. (1999). Are Asian Stock Markets Fluctuation Due Mainly to Intra-regional Contagion Effects? Evidence Based on Asian Emerging Stock Markets. Pacific-Basin Finance Journal, 7, 251-282. http://dx.doi.org/10.1016/S0927-538X(99)00013-X

Masih, A. M., \& Masih, R. (2002). Propagative causal price transmission among international stock markets: Evidence from the pre-and-post globalization period. Global Finance Journal, 13(1), 63-91. http://dx.doi.org/10.1016/S1044-0283(02)00039-X

Mishra, A. K. (2002). International Financial Integration of Domestic Financial Markets: A Study of India. The ICFAI Journal of Applied Finance, 8(2), 5-15.

Modi, A., Patel, B., \& Patel, N. (2010). The Study on Co-Movement of Selected Stock Markets. International Research Journal of Finance and Economics, 47, 171-183.

Mukharjee, K. N., \& Mishra, R. K. (2005). Stock Market Interlink ages: A study of Indian and World Equity Markets. Indian journal of Commerce, 58(1), 17-42.

Mukherjee, K., \& Mishra, R. K. (2007). International Stock Market integration and its economic determinants: A study of Indian and world equity market. Vikalpa, 32(4), 29-44.

Park, Y. S. (1999). Characters and Measurement Indicators of International Financial Integration in Developing Countries. George Washington University, Washington D.C.

Phillips, P. C. B., \& Perron, P. (1988). Testing for a Unit Root in Time Series Regression. Biometrika, 75(2). http://dx.doi.org/10.1093/biomet/75.2.335

Prasad, E., Rajan, R., \& Subramanian, A. (2006). Patterns of international capital flows and their implications for economic development. Presented at the symposium, 'The New Economic Geography: Effects and Policy Implications', The Federal Reserve Bank of Kansas City, Jackson Hole, Wyoming, 24-26 August.

Reserve Bank of India. (2007). Financial Market Integration. Chapter VIII, RBI Annual Report.

Siklos, P. L., \& Ng, P. (2001). Integration among Asia-Pacific and International Stock Markets: Common Stochastic Trends and Regime Shifts. Pacific Economic Review, 6, 89-110. http://dx.doi.org/10.1111/1468-0106.00120

Vo, X. V., \& Daly, K. J. (2005). European Equity Market Integration- Implication for US Investors. Journal of Research in International Business and Finance, 19(1), 155-170. http://dx.doi.org/10.1016/j.ribaf.2004.10.007

Voronkova, S. (2004). Equity market integration in central European emerging markets: a cointegration analysis with shifting regimes. International Review of Financial Analysis, 13, 633-647. http://dx.doi.org/10.1016/j.irfa.2004.02.017

Wong, W. K., Agarwal, A., \& Du, J. (2005). Financial integration for India stock market, a fractional cointegration approach. Departmental Working Paper, wp0501, Department of Economics, National University of Singapore.

\section{Copyrights}

Copyright for this article is retained by the author(s), with first publication rights granted to the journal.

This is an open-access article distributed under the terms and conditions of the Creative Commons Attribution license (http://creativecommons.org/licenses/by/3.0/). 